
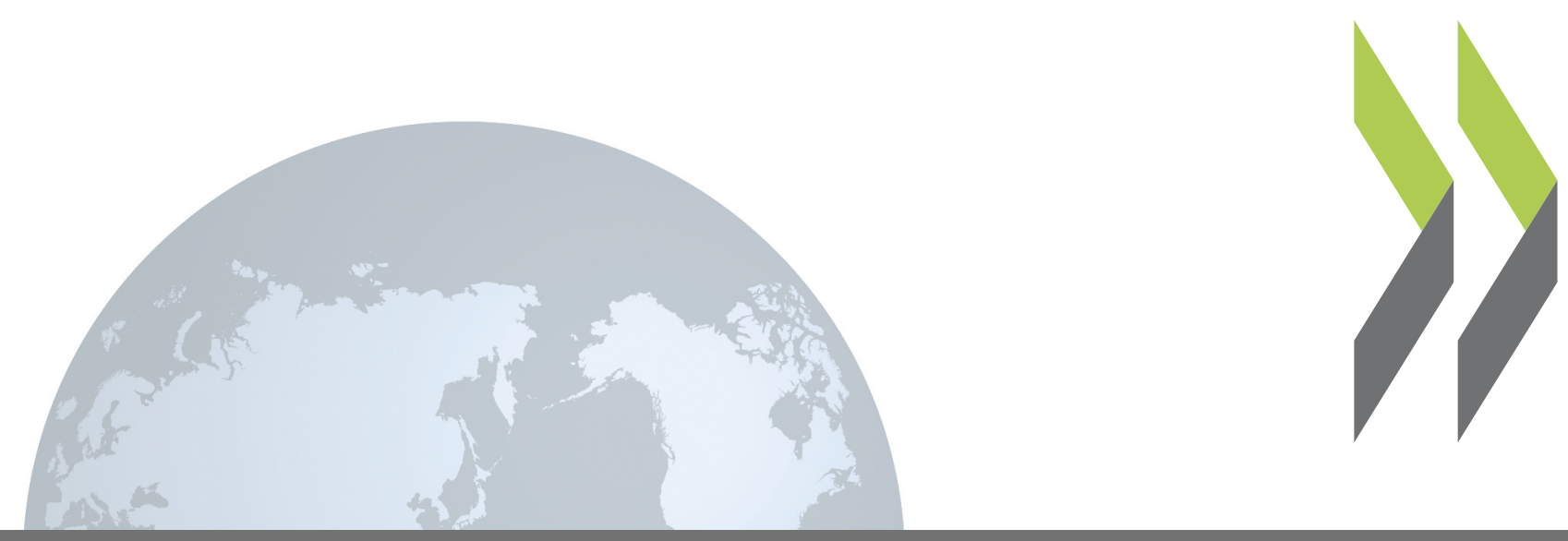

OECD Trade and Environment Working Papers 2018/03

\title{
International Trade and the Transition to a More Resource Efficient and Circular Economy: A Concept Paper
} Shunta Yamaguchi 


\section{OECD TRADE AND ENVIRONMENT WORKING PAPERS}

The OECD Trade and Environment Working Paper series is designed to make available to a wide readership selected studies by OECD staff or outside consultants.

OECD Working Papers should not be reported as representing the official views of the OECD or of its member countries. The opinions expressed and the arguments employed are those of the authors.

Working Papers describe preliminary results or research in progress by the author(s) and are published to stimulate discussion on a broad range of issues on which the OECD works. Comments on Working Papers are welcomed, and may be sent to the Environment Directorate or the Trade and Agriculture Directorate, OECD, 2 rue André-Pascal, 75775 Paris Cedex 16, France. Comments on Working Papers may also be sent to env.contact@oecd.org or tad.contact@,oecd.org.

This document has been prepared under the auspices of the Joint Working Party on Trade and Environment (JWPTE) and declassified by the Environment Policy Committee (EPOC) under the OECD reference number COM/TAD/ENV/JWPTE(2018)3/FINAL.

The publication of this document has been authorised by Rodolfo Lacy, Director, Environment Directorate, OECD.

\section{OECD TRADE AND ENVIRONMENT WORKING PAPERS}

are published on the OECD's trade (www.oecd.org/trade) and environment (www.oecd.org/environment) web pages, as well as on the OECD iLibrary web pages (www.oecdilibrary.org).

This document and any map included herein are without prejudice to the status of or sovereignty over any territory, to the delimitation of international frontiers and boundaries and to the name of any territory, city or area.

You can copy, download or print OECD content for your own use, and you can include excerpts from OECD publications, databases and multimedia products in your own documents, presentations, blogs, websites and teaching materials, provided that suitable acknowledgment of OECD as source and copyright owner is given. All requests for commercial use and translation rights should be submitted to rights@oecd.org. 


\title{
INTERNATIONAL TRADE AND THE TRANSITION TO A MORE RESOURCE EFFICIENT AND CIRCULAR ECONOMY - CONCEPT PAPER
}

\author{
Shunta Yamaguchi
}

The transition towards a more resource efficient and circular economy has broad linkages with international trade through the emergence of global value chains as well as trade in second-hand goods, end-of-life products, secondary materials and waste. Despite of the potential linkages between trade and the circular economy, the existing research on this issue is limited to date.

For this reason, this paper highlights the potential interaction of international trade and the circular economy in order to map out potential issues to address and to guide further research areas to explore on this topic. The paper first briefly introduces the circular economy concept and how trade can come into play, second highlights the various ways in which trade and the circular economy can potentially interact with one another, and third briefly concludes with potential ways forward and next steps.

JEL classification: F18, Q53, O13, Q56.

Keywords: circular economy, resource efficiency, sustainable materials management, trade and environment, environment policy, trade policy.

\section{Résumé}

La transition vers une économie circulaire plus efficace dans l'utilisation des ressources est très liée au commerce international par l'émergence de chaînes de valeur mondiales et par le commerce de biens d'occasion, de produits en fin de vie, de matières secondaires et de déchets. Malgré les liens potentiels entre le commerce et l'économie circulaire, les recherches existantes sur cette question sont limitées à ce jour.

Pour cette raison, le présent document met en évidence l'interaction potentielle du commerce international et de l'économie circulaire afin de définir les problèmes potentiels à résoudre et d'orienter les domaines de recherche futurs à explorer sur ce sujet. Le document présente d'abord brièvement le concept d'économie circulaire et la manière dont le commerce peut entrer en jeu, puis met en évidence les différentes manières dont le commerce et l'économie circulaire peuvent potentiellement interagir et enfin conclut brièvement en proposant des pistes de progression et les prochaines étapes.

Classification JEL : F18, Q53, O13, Q56

Mots clés : économie circulaire, efficacité des ressources, gestion durable des matériaux, les échanges et l'environnement, politique de l'environnement, politique commerciale. 


\section{Ackowledgments}

This report is part of the work mandated under the 2017-18 Programme of Work and Budget of the Environment Policy Committee under output result 2.3.4.1.3: Macroeconomic Consequences of Resource Efficiency and the Transition to a Circular Economy. The work was conducted under the auspices of the Joint Working Party on Trade and Environment (JWPTE).

The report was authored by Shunta Yamaguchi of the OECD Secretariat. Delegates to the JWPTE as well as the Environment Policy Committee (EPOC) provided important comments on earlier drafts. OECD colleagues including Peter Börkey, Andrew McCarthy, Ruben Bibas, Aleksandra Paciorek, Jane Korinek and Grégoire Garsous provided valuable input and suggestions. Katjusha Boffa provided editorial assistance. Work on this paper was conducted under the overall supervision of Shardul Agrawala, Head of the Environment and Economy Integration Division. The authors are responsible for any remaining omissions or errors.

This document has been produced with the financial assistance of the European Union. The views expressed herein do not necessarily reflect the official views of the OECD or of the governments of its member countries and can in no way be taken to reflect the official opinion of the European Union. 


\section{Table of contents}

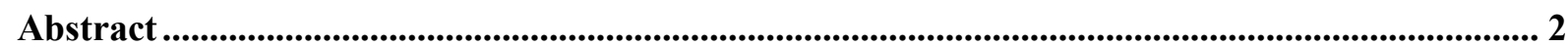

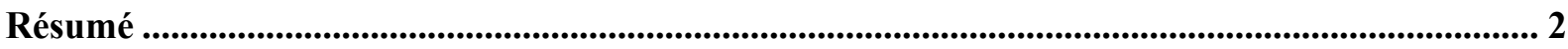

Ackowledgments ............................................................................................................................................... 3

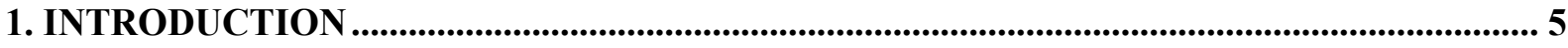

2. SIGNIFICANCE OF TRADE IN A CIRCULAR ECONOMY TRANSITION......................... 5

3. THE INTERFACE OF INTERNATIONAL TRADE AND THE CIRCULAR ECONOMY .... 8

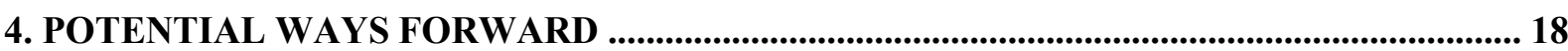

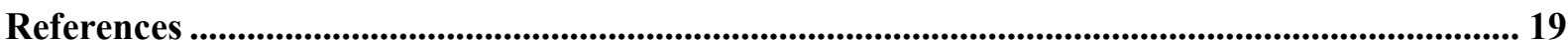




\section{INTRODUCTION}

A transition towards a more resource efficient and circular economy is gaining political attention across the globe. Many countries are taking action to adopt circular economy policies by closing material loops through the promotion of reuse, recycling and new business models, extending material loops through eco-design, and narrowing loops through resource efficiency initiatives. While these policies are largely considered at the domestic level, there is increasing awareness that a transition towards a more resource efficient and circular economy has broad linkages with international trade. This for instance takes place through the emergence of global value chains as well as trade in second-hand goods, end-of-life products, secondary materials or non-hazardous waste, as well as trade in related services.

Despite of the potential linkages between trade and the circular economy, the existing research on this issue is limited to date. For this reason, this paper sets forth the potential interaction of international trade and the circular economy in order to guide further research areas to explore on this topic. The paper first briefly introduces the circular economy concept and how trade can come into play, second highlights the various ways in which trade and the circular economy can potentially interact with one another, and third briefly concludes with potential ways forward and next steps.

\section{SIGNIFICANCE OF TRADE IN A CIRCULAR ECONOMY TRANSITION}

Natural resources form fundamental elements to sustain our physical economy. In recent years, the increase in global population and economic growth has intensified global material consumption which has more than doubled since 1980 (OECD, 2016a). By 2050, global population is projected to increase from 7 billion to 9 billion and per capita income is expected to roughly triple leading to a two-fold increase in global material consumption levels (OECD, 2012a). The surge in natural resource demand will increase environmental pressures that arise from the extraction, consumption and end-of-life management of such resources and calls for their sustainable use.

The circular economy has become an increasingly popular term in recent years in this context. While there is no universally agreed definition of the circular economy to date, the OECD working paper by McCarthy et al. (2018a) illustrates this as a concept to use resources more efficiently across their life-cycle by closing, extending and narrowing material loops that could result in decoupling of primary raw material consumption from 
economic growth. ${ }^{1}$ The transition to a circular economy generally entails approaches that may lead to lower rates of extraction and use of natural resources, including through resource efficiency policies as well. The circular economy concept, therefore, complements to improve resource efficiency (where more economic value is produced with a particular amount of resources (McCarthy et al., 2018a)) and Sustainable Materials Management (to promote sustainable materials use targeted at reducing negative environmental impacts and preserving natural capital throughout the life-cycle of materials (OECD, 2012b)).

Four key benefits of the transition to a circular economy are commonly identified in the literature: (i) reduced extraction of virgin natural resources; (ii) lessened exposure to (geo-political) supply risk; (iii) reduced environmental pressures; and (iv) new economic opportunities. Synergies between the transition to a circular economy and low-carbon economies also arise from the shift in the use of primary raw materials to secondary raw materials, which generally involves less energy intensive processes that could lead to a reduction in carbon emissions depending on the energy mix. The circular economy transition can also provide potential benefits by generating new employment opportunities (McCarthy et al., 2018a).

Political interest in the transition to a more resource efficient and circular economy is emerging in various corners of the world. At the international level, efforts towards a resource efficient economy began in the late $2000 \mathrm{~s}^{2}$ and have achieved increased emphasis more recently in the framework of the G7 Alliance on Resource Efficiency, UN Sustainable Development Goals, and the European Union Circular Economy Action Plan. At the national level, policy action has taken place for instance in China, Finland, France, and the Netherlands in establishing circular economy roadmaps, Japan in implementing the Fundamental Law for Sound Material-Cycle Society, and the United States in launching the Sustainable Materials Management Action Plan (McCarthy et al., 2018a).

Circular economy initiatives are largely facilitated through domestic policies. Policy action to close, extend and narrow material loops are commonly considered at the national level (e.g. GGKP, 2015). For instance, Extended Producer Responsibility (EPR) schemes, landfill taxes, and industrial partnerships to encourage design for the environment are generally implemented within national jurisdictions (OECD, 2016b). More broadly, waste management and material recovery is also encouraged to take place domestically. For instance, the European Commission as a part of its Waste Framework Directive has a proximity principle suggesting that waste should be disposed of as close to the source of generation as possible (European Commission, 2008). In the international context, the Control of Transboundary Movements of Wastes Destined for Recovery Operations (OECD Council Decision) ${ }^{3}$ and the Basel Convention on the Control of Transboundary Movements of Hazardous Wastes and Their Disposal (Basel Convention) ${ }^{4}$ provide restrictions to international trade in hazardous waste.

Nevertheless, the circular economy transition can have several implications for international trade. First, a number of studies focusing on the global aggregate level indicate that international trade shifts virtual material consumption levels through hidden indirect

1 See McCarthy et al. (2018a; pp. 11-12) Box 1 for further discussion on different concepts including circular economy, resource efficiency, secondary materials and decoupling.

2 Some of these global efforts include the OECD Council Recommendation on Resource Productivity (2008) and the G8 Kobe 3R Action Plan (2008).

3 See: www.oecd.org/environment/waste/30654501.pdf.

4 See: www.basel.int/Portals/4/Basel\%20Convention/docs/text/BaselConventionText-e.pdf. 
flows of materials embedded in traded products. Domestic material consumption (DMC) is a frequently used indicator to measure the amount of resources directly consumed by economic activities and accounts for the amount of primary raw materials used in an economy. A complementary indicator is total material consumption (TMC) which measures the amount of resources used in an economy, both directly through primary raw materials and indirectly through materials embedded in traded products (OECD, 2015a). The material footprint of economies, that is the total consumption of raw materials and their equivalents in products, tend to increase significantly when considering the TMC in comparison to DMC (OECD, 2016b; Giljum et al., 2014; Wiedmann et al., 2013). This means that decoupling efforts of material consumption from economic growth is not correctly captured without proper consideration of international trade patterns.

Second, as recently seen in the fragmentation of global value chains, products and their components are increasingly being procured across borders from different countries (De Backer and Miroudot, 2013; OECD, 2013; Kowalski et al., 2015) and similarly, when products reach their end-of-life, they can be exported to other countries as secondary goods for further consumption, secondary materials for production feedstock, or materials and waste for further processing. For example, iron and steel scrap is traded globally reaching an overall trade value of USD 29.9 billion which accounts for $7 \%$ of global iron and steel trade in 2015 (Chatham House, 2017). Second-hand cars are frequently traded internationally from OECD to non-OECD countries. In 2014, international trade of used cars from top five exporters of Canada, Japan, Korea, Mexico and the United States reached a trade value of USD 13.9 billion amounting to $6 \%$ of their total annual passenger car exports. These were destined to non-OECD countries involving the top five markets of the United Arab Emirates, the Russian Federation, Nigeria, Mexico, and Myanmar (Coffin et al., 2016). According to the European Commission (2015a), the EU is currently the largest exporter of non-hazardous waste to non-OECD countries for recovery operations that amounted to EUR 8.1 billion with significant fractions destined to China $(30.7 \%)$ and India $(11.5 \%)$ in 2014.

There is increasing awareness of the opportunities and challenges that arise at the interface of international trade and the circular economy. The OECD (2016a) policy guidance on resource efficiency calls for a need to better address trade related obstacles to resource efficiency in supply chains such as export restrictions on secondary materials, and restrictions to trade in secondary goods and used products. There are other studies that investigate the potentially missed opportunity with regards to increased exports in nonhazardous waste and suggest for more recovery and utilisation of secondary raw materials domestically to serve national interests, such as in the recommendations made in the context of the United Kingdom by the Associate Parliamentary Sustainable Resource Group (2013). The emerging interests as well as diverging recommendations indicate that there is potential for further investigation. 


\section{THE INTERFACE OF INTERNATIONAL TRADE AND THE CIRCULAR ECONOMY}

The transition towards a circular economy entails the utilisation of resources in the economy by: (1) closing material loops through: (i) the promotion of repair, reuse, refurbishment and remanufacturing of end-of-life products; (ii) the recycling of postconsumer material and waste into secondary raw materials, and (iii) promoting productservice-systems; (2) extending material loops through eco-design, and (3) narrowing loops through resource efficiency initiatives (McCarthy et al., 2018a). Current policy action largely focuses on achieving material circularity at the domestic level as illustrated in solid arrows in Figure 1. However, international trade occurs at various levels along the product value chain, such as trade in materials and waste for recycling and energy recovery, trade in secondary raw materials, trade in second-hand goods and trade in goods for refurbishment and remanufacturing, as shown in the dotted arrows in Figure 1. To avoid complexity, exports are mainly shown in this diagram. However, imports can similarly occur in the transition to a circular economy such as secondary raw materials as feedstock or notably services trade to enhance product service systems.

In this concept paper, seven key issues are identified in the nexus of international trade and the circular economy as potential areas for further investigation: (i) the potential impacts of the circular economy transition on trade; (ii) the interaction of trade and domestic circular economy policies; (iii) trade in waste and scrap for recovery; (iv) trade in secondary raw materials; (v) trade in second-hand goods for reuse; (vi) trade in goods for refurbishment and remanufacturing; and (vii) international co-operation on circular economy value chains. These potential areas are further elaborated as follows. 
Figure 1. Linkages between international trade and the circular economy

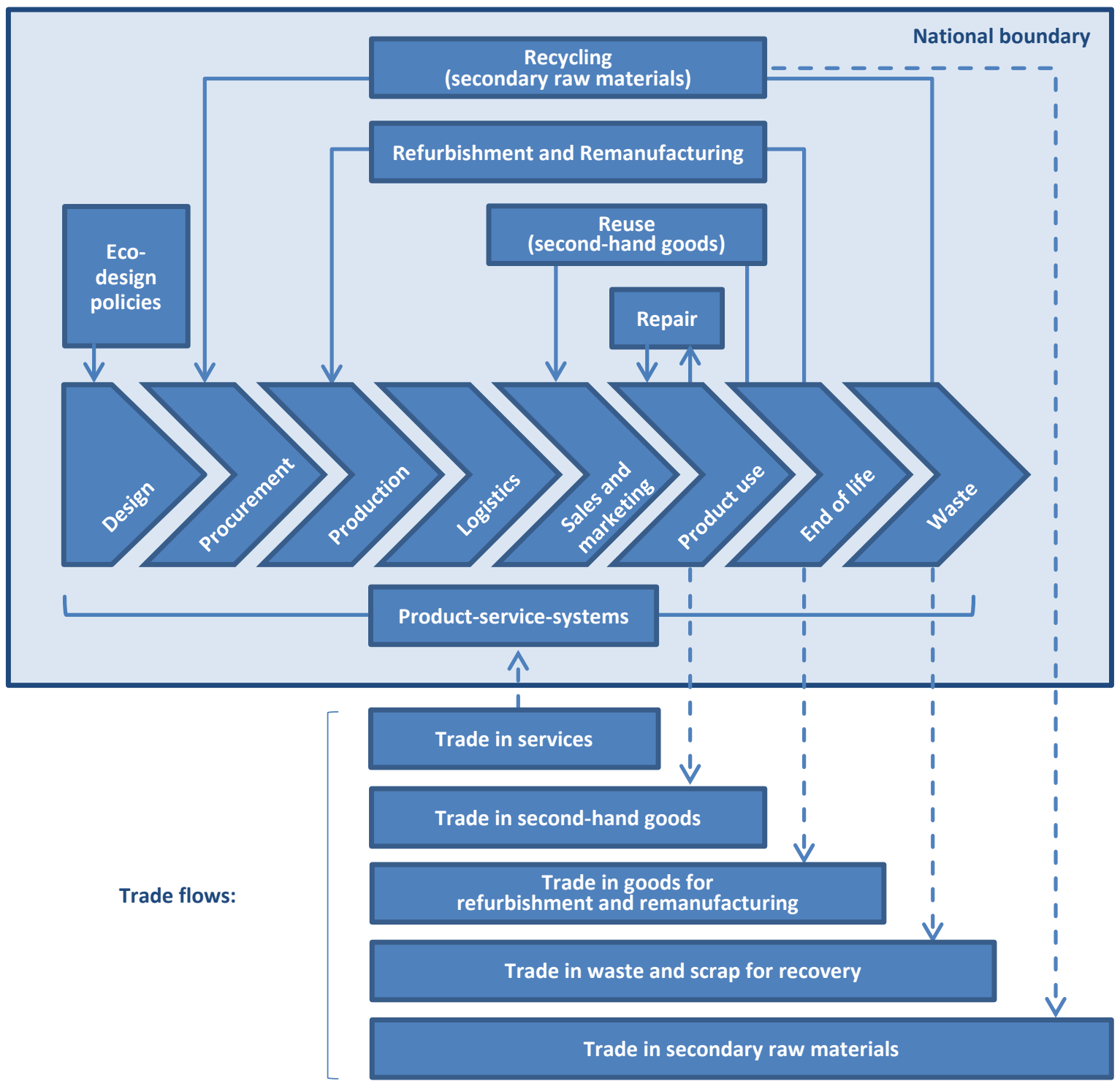

Notes: Solid arrows represent domestic flows; dotted arrows represent international trade flows.

Source: Author, based on McCarthy et al. (2018b), Lacy and Rutqvist (2015) and Rabobank (2015).

\subsection{Potential impacts of the circular economy transition on trade flows}

International trade flows may shift according to the wide-ranging structural changes in production and consumption patterns induced by a transition towards a circular economy. A circular economy transition entails an increase in the circularity of materials and reduces primary resource inputs. Therefore, the transition can undermine the import 
demand of primary and secondary materials in a given jurisdiction. Similarly, exports of materials and waste may also decrease (Preston and Lehne, 2017).

Typically, the circular economy transition tends to boost service sectors relative to manufacturing sectors. Service-intense sectors such as waste management, recycling, refurbishment and remanufacturing, reuse, and repair are expected to grow as manufactures substitute secondary raw materials for primary raw materials and consumers substitute services for goods (McCarthy et al., 2018a). Many goods can also be replaced by services where the end user buys a service instead of the good itself (Valles, 2016). As an example, some lighting companies are exploring the possibility to provide lighting services instead of selling light bulbs and to retain ownership of its lighting equipment, from installation and maintenance, to end-of-life recovery (McCarthy et al., 2018b).

These product service systems are frequently cited as a part of new business models for the circular economy (McCarthy et al., 2018b) and may provide new opportunities for international trade. For example, circular economy business models may trigger services trade that may not be captured as tangible goods in import-export statistics, such as software solutions that involve reuse and refurbishment rather than ownership of in-country products For these reasons, the circular economy transition entails the shift of trade not only of goods, but also of services.

Furthermore, green public procurement that reflects circular economy and resource efficiency objectives may provide additional opportunities for international trade. Indeed, in $2015,84 \%$ of OECD countries incorporated policies aimed at green public procurement (OECD, 2016a). In some cases, circular procurement guidelines are made available for public entities as those developed by the European Commission in 2017. ${ }^{5}$ While general government procurement accounted for 12\% of GDP and around one-third of government expenditures in 2015 (OECD, 2016a), circular procurement by subnational and national governments may offer new international trade opportunities to innovative companies.

\subsection{Interaction of trade and domestic circular economy policies}

The intention to promote a circular economy at the national level has at times raised concerns of creating unnecessary trade barriers and has led to disputes between trading partners with regards to trade and domestic policies. At the multilateral level, WTO disputes have been recorded in 2013 in two cases raised by the European Union and Japan where it is claimed that the Russian Federation imposed a recycling fee on motor vehicles giving preferable conditions to domestic manufactures over their foreign counterparts. ${ }^{6}$ The cases are pending final decisions as of July 2018. At the regional level, several disputes have been raised in the context of investor-state dispute settlement under the North American Free Trade Agreement (NAFTA) in force since 1994. The most relevant case to the circular economy is the "Myers v. Canada" case raised in 1998 where Canadian authorities were

5

See:

http://ec.europa.eu/environment/gpp/pdf/Public_procurement_circular_economy_brochur e.pdf.

See WTO dispute cases DS462 and DS463 available at:

www.wto.org/english/tratop_e/dispu_e/find_dispu_cases_e.htm. 
challenged by a waste management company based in the United States for imposing export bans on Polychlorinated Biphenyl (PCB) waste. ${ }^{7}$

Similar concerns have been raised in the application of Extended Producer Responsibility (EPR) schemes. Although the extent to which the adoption of these schemes has led to disputes under trade rules is unknown, the earlier OECD guidance document indicates that EPR schemes should be non-discriminatory and avoid the creation of unnecessary trade barriers (OECD, 2004; 2001).

At the same time, it is important to ensure that international trade rules do not hinder the adoption of circular economy and resource efficiency policies as indicated in the OECD (2016a) policy guidance on resource efficiency. To facilitate the transition towards a more resource efficient and circular economy, governments commonly consider adopting domestic policies such as EPR schemes, standards for recycled materials, standards for recyclability and reparability of products, requirements for eco-design, requirements to secure information on chemical and material composition of products, and to phase-out hazardous substances from products. While these domestic initiatives can bring about positive outcomes, they can also face challenges, as products are widely involved in global value chains through international trade and exposed to different regulations and standards based on various levels of environmental stringency across multiple jurisdictions worldwide. For instance, despite upstream efforts along the product lifecycle to phase out hazardous substances from products to increase their potential recycling rates, imported goods from abroad that do not necessarily meet the same standards or requirements may still enter downstream waste recovery processes.

This implies that although domestic policies are increasingly in place to pursue circular economy objectives, domestic policies alone may not be enough to facilitate a transition towards a global circular economy. There is a question to whether further efforts are required at the global or regional level, such as revisiting trade disciplines, or considering global or regional recyclability and reparability standards, requirements on ecodesign, requirements to provide information on chemical and material composition of products, mutual recognition of schemes, and possible international co-operation.

Since the transition towards a circular economy entails the application of new and innovative policies, there could be potential additional issues to investigate in the nexus of trade policies and the circular economy transition.

\subsection{Trade in waste and scrap}

There is a long-standing concern that trade flows in waste could be negative for the environment and should largely be avoided. International trade in waste is regulated by multilateral environmental agreements such as the OECD Council Decision and the Basel Convention. These controls are in place to make sure that trade in such materials, especially trade in hazardous waste, does not create negative effects for the environment. At the national and regional level, a proximity principle is commonly applied to ensure that waste is treated as close as possible to the point of generation, as indicated in the Waste Framework Directive of the European Union (European Commission, 2008). 
However, there is growing awareness on the importance of treating waste as a resource and a major trading good. Indeed, waste trade can provide potential opportunities to direct waste to countries with comparative advantage in sorting and processing activities that can help boost global recycling rates (OECD, 2018). Post-consumer materials and waste have intrinsic value for material and energy recovery and therefore there is increasing recognition that non-hazardous waste could be traded for further processing and recovery under proper controls (Associate Parliamentary Sustainable Resource Group, 2013; European Commission, 2015a). For instance, in 2014, India accounted for 13\% of global secondary steel production despite limited supplies of domestic steel scrap which implies that trade in waste and scrap for material recovery has played an important role (McCarthy et al., 2018a). Further studies emphasise that imposing trade restrictions on waste and scrap can even potentially undermine production efficiency in emerging economies (in particular advanced developing countries) by limiting the supply of feedstock material at low prices (Higashida and Managi, 2014).

To the best of our knowledge, there are no readily available statistics on trade in waste destined for processing and recovery to date. In other words, available information on trade in waste and scrap does not easily enable to distinguish how these materials are treated at their destination. The Basel Convention website ${ }^{8}$ provides data on transboundary movement of hazardous waste and other waste (i.e. household waste and incinerator ash from household waste) and this could be a starting point to understand the trends and magnitude of such trade flows. ${ }^{9}$ Correspondence tables between waste codes and the Harmonised System (HS) ${ }^{10}$ are also made available by the Secretariat of the Basel Convention (2013) as well as individual studies by Kellenberg (2012), which enables to complement data on international trade flows of waste.

Dwelling on the waste and HS codes identified by Kellenberg (2012), the OECD is currently developing indicators on waste and scrap trade as a part of its work on indicators for trade and the environment (OECD, forthcoming). Preliminary results show that global trade in waste and scrap reached 227 million tonnes in weight and USD 96 billion in value in 2016. Over the period of 2003 to 2016 , the amount of trade increased by $48 \%$ in weight and $183 \%$ in value. These trends imply that the value of waste and scrap has significantly increased during the past decade. The majority of these trade flows consisted of metal, paper and plastic waste and scrap which all together accounted for $97 \%$ in total value and $94 \%$ in total weight in 2016 (Figure 2).

www.basel.int/Countries/NationalReporting/NationalReports.

This data is available from national reports provided by Basel Parties on an annual basis as part of Basel reporting requirements. Many countries, however, do not submit annual reports and so the data may not be representative of trade by all Basel Parties.

The Harmonized Commodity Description and Coding System generally referred to as "Harmonized System" or simply "HS" is a multipurpose international product nomenclature developed by the World Customs Organization (WCO) to classify internationally traded products. See:

www.wcoomd.org/en/topics/nomenclature/overview/what-is-the-harmonizedsystem.aspx. 
Figure 2. Trade in waste and scrap between 2003 and 2016

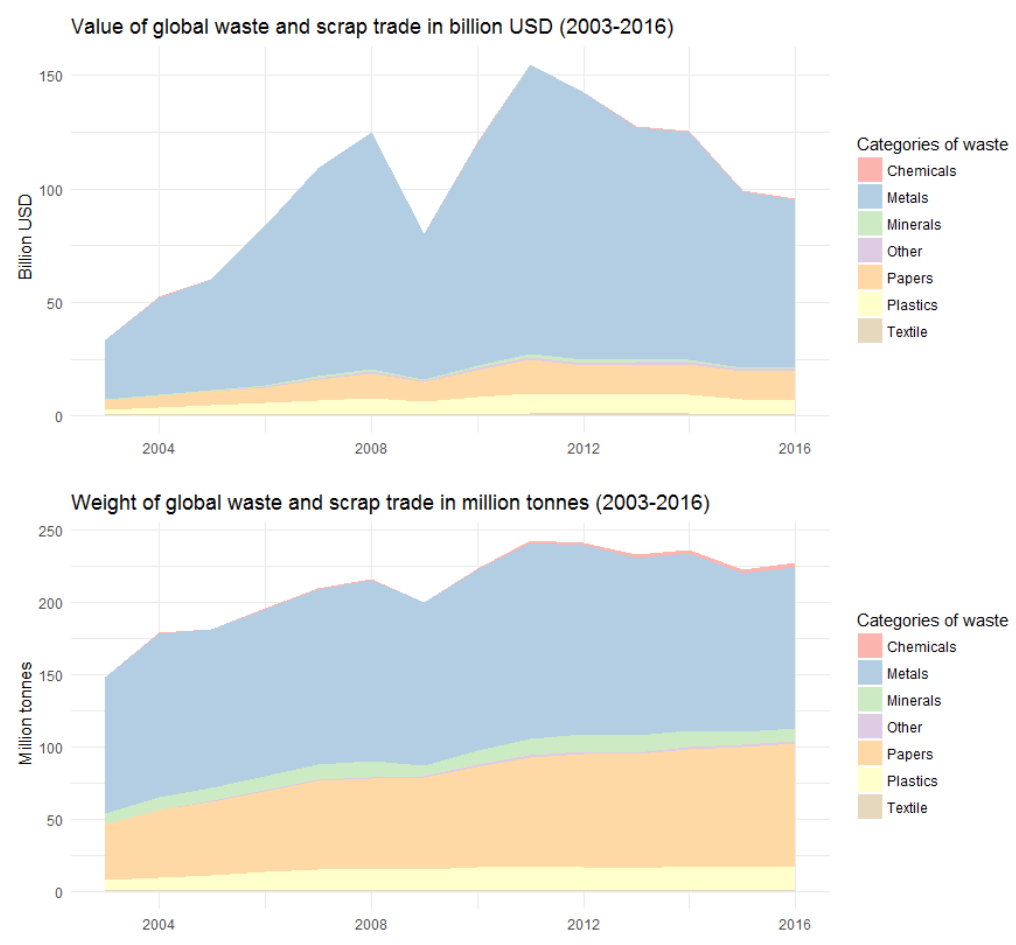

Source: OECD (forthcoming), Indicators on Trade and Environment

One potential issue identified by the Secretariat to the Basel Convention (2013) as well as the OECD (2010) study in understanding the volume of trade in waste and scrap for recovery is that the definition and classification of waste, scrap and secondary materials can be different from country to country. The distinction between end-of-life products, nonhazardous waste, and secondary raw materials may not be the same across different jurisdictions and subject to further scrutiny.

As worldwide volume of trade in waste and scrap is rapidly increasing, potential concerns are raised in some export destinations on the environmentally sound management of waste. Kellenberg (2012) finds evidence that bilateral trade in waste increases if there is divergence in environmental policy stringency between the trading partners. This implies that there could be a pollution haven effect where waste is destined to countries with laxer environmental standards in some cases. There are particular concerns with the increase of bilateral flows in waste destined to emerging economies and developing countries with underdeveloped waste management capacity (Farrelly et al., 2016; Yanai, 2014). Claiming that waste imports are polluting the environment, China has announced to impose import restrictions on waste and scrap taking effect in several phases starting from January 2018 (See Box 1).

However, trade flows in waste and scrap in itself does not indicate an increase or decrease in environmental pressures. The question is rather if traded waste and scrap is processed and recovered in an environmentally sound manner and closely in-line with circular economy objectives (OECD, 2010; Shinkuma and Managi, 2011). More ambitiously, it would be important to understand to what extent waste and scrap trade 
potentially contributes to upcycling and downcycling. In this sense, distinguishing trade in waste for material recovery and trade in waste as residuals intended for energy recovery would be particularly important despite the potentially challenging task.

\section{Box 1. China's import restriction on waste and scrap}

China made three notifications to restrict imports on waste and scrap. Two WTO notifications were made on 18 July 2017 and 15 November 2017. The prior listed 24 types of waste and scrap to be prohibited for imports from 1 January 2018 and the latter set forth a maximum level of contamination $(0.5 \%$ by weight $)$ for 11 categories of waste and scrap to come into effect from 1 March 2018. ${ }^{11}$ A further announcement was made on 13 April 2018 to further add 32 categories of waste and scrap to be prohibited for imports taking effect sequentially either from 31 December 2018 or 31 December $2019 .{ }^{12}$ All of these trade restrictions are applied with the motivation to prevent and control environment pollution. While trade effects are in question, these measures have potential consequences in two ways. First, for exporters lacking domestic capacity to process these materials, the restrictions may provoke increased domestic incineration and landfilling (at least in the short term). Second, the trade restrictions can risk diverting waste and scrap exports to countries with relatively weak treatment standards including alternative sinks in South and South-East Asia (see Figure 3).

Figure 3. Monthly exports of waste and scrap from the EU by destination 2016-2018
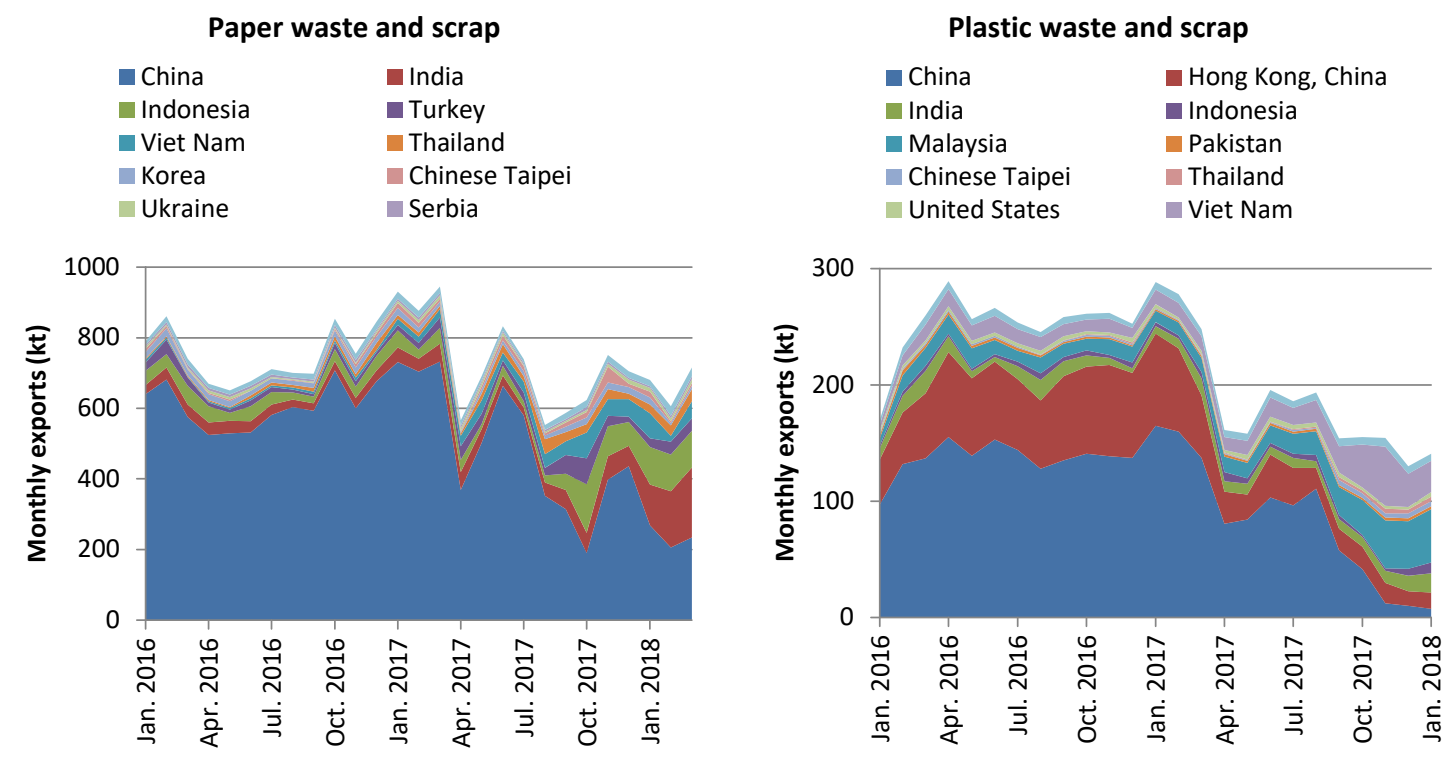

Note: Paper waste and scrap (HS code 470710; 470720; 470730), Plastic waste and scrap (HS code 3915)

Source: Author(s) based on Eurostat and OECD (2018)

11 See: WTO notifications G/TBT/N/CHN/1211 and G/TBT/N/CHN/1233.

12 See: www.bir.org/assets/Documents/China/Legislation/2018/Announcement-No.-6-of2018-Final.pdf. 
Another potential issue is illegal trade in waste. A number of studies make theoretical investigations and indicate that there could be a structural incentive towards illegal trade in hazardous waste (See Dato, 2017; Bernard, 2015; Higashida, 2012; Kellenberg, 2012; and Shinkuma and Managi, 2011; 2010). Another study complements this approach by investigating and surveying the nature of illegal trade in waste of electric and electronic equipment (WEEE or e-waste) in the European context (Huisman et al., 2015). The study estimates that among the 9.45 million tons of e-waste generated in Europe in 2012 , only $35 \%$ of them were collected and recycled in official systems while the remaining $65 \%$ were either exported $(16 \%)$, recycled under non-compliant conditions in Europe $(33 \%)$, processed by the informal sector $(8 \%)$, or simply discarded in waste bins $(8 \%)$. It also estimates that 1.3 million tons $(14 \%)$ of e-waste departed the EU in undocumented exports that would likely be classified as illegal waste trade. Similarly, in France, it is estimated that only one third of e-waste generated in its territory are directed towards official EPR systems while between $45 \%$ and $75 \%$ are either handled by informal systems or exported. In Japan, approximately half of end-of-life home appliances are captured by official EPR systems while the other half is channelled through the informal sector and second-hand product markets (OECD, 2016b). Informal recycling activities, especially in the case of informal e-waste processing in developing countries, often involve toxic emissions and dumping of waste acid without any proper treatment or controls that can lead to severe environmental and health concerns (OECD, 2016b; Shinkuma and Managi, 2011). Therefore, this poses a serious question to whether an increase in waste trade would actually be good for the environment.

Finally, removing barriers to trade in environmental goods and services could possibly encourage environmental sound management in waste. The OECD study by Sauvage (2014) indicates that, in 2011, 9\% of global trade in environmental goods concerned those related to the management of solid and hazardous waste and recycling systems. To this end, international trade could possibly contribute to the transition towards a circular economy. The magnitude of such effects could be further investigated.

Overall, it is important to acknowledge that trade in waste and scrap can provide potential opportunities to channel these materials to countries with comparative advantage in sorting and possessing them to advance towards a more global circular economy, while ensuring that these benefits are not at the expense of environmental externalities (Higashida and Managi, 2014). The issue of trade in waste and scrap as a part of the discussion on the transition towards a circular economy is extremely complex and merits further investigation.

\subsection{Trade in secondary raw materials}

Trade in secondary raw materials constitutes a very important element of the trade and circular economy interface. The substitution of primary raw materials by secondary raw materials would encourage decoupling by decreasing demand for primary materials while sustaining levels of economic growth. Since natural resources are geographically unequally concentrated, trade implications are significant in the worldwide distribution of primary raw materials (WTO, 2010). For example, in 2013, 43\% of global production of iron ore was exported outside of the country of origin (McCarthy and Börkey, 2018). Similarly, exports of secondary raw materials are also concentrated in certain parts of the world. For instance, the European Union, Japan and the United States are identified as the largest exporters of scrap metal (McCarthy and Börkey, 2018). To this end, trade in secondary raw materials is extremely important in the transition to a circular economy. 
However, there is currently no internationally accepted definition of secondary raw materials and tracking such trade flows is therefore difficult. In the OECD (2010) study on non-hazardous recyclable materials, HS codes on metal scrap, scrap paper and plastic scrap are identified and could provide a starting point. This could be complemented by the HS codes of waste compiled by Kellenberg (2012) and the correspondence table made available by the Secretariat of the Basel Convention (2013).

Global trade patterns for steel scrap are illustrated in Figure 4. It shows that trade volumes in steel scrap have been generally growing in the past 25 years and OECD countries largely account for these trade flows. The recent plunge in terms of monetary value partly indicates the volatility in market prices for steel scrap.

Figure 4. Trade in steel scrap between 1989 and 2015

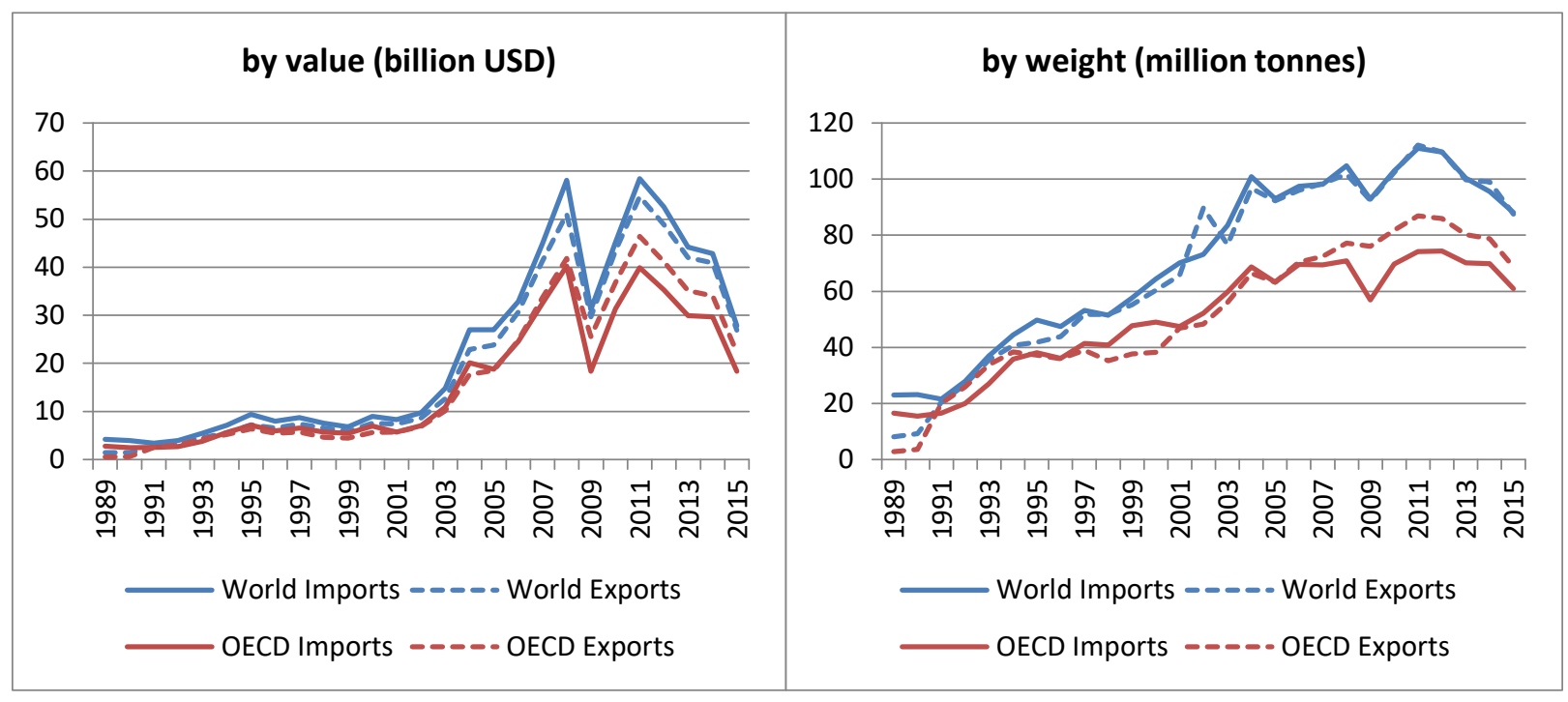

Source: Author based on COMTRADE data ${ }^{13}$

In order to enhance the utilisation of secondary raw materials, removing barriers to trade on secondary raw materials is gaining attention. In the context of the European Union, the lack of adequate tools and standards to ensure the quality of secondary raw materials to enhance their utilisation and trade are identified as potential barriers that should be addressed (European Commission, 2015b).

In relation to the adoption of recyclability standards, an important aspect is to ensure that products are designed in a way that they are easier to recycle and refrain from using hazardous content. Similarly, securing information on chemical and material composition of products is of particular importance to ensure the recyclability of end-oflife products. With the emergence of global value chains, eco-design and eco-labelling schemes may also play an important role to facilitate a transition to a global circular economy (OECD, 2016a; 2016b; Prag et al., 2016). These schemes need to be taken with care so that they do not act as excess barriers to access international markets (Prag et al.,

13 Based on HS codes720410; 720421; 720429; 720430; 720441; 720449. The difference between exports and imports (at world level) can be due to: (1) classification concepts; (2) time of recording; (3) valuation; and (4) processing errors. 
2016). Collective effort at the international level, such as global recyclability standards, may also be required to maximise the impact of these schemes.

Furthermore, in light of national interests, export restrictions are frequently applied to secondary raw materials (OECD, 2014a). The OECD database on export restrictions indicates that roughly one-third of export restrictions on raw materials between 2009 and 2014 were applied to waste and scrap (OECD, 2017). The OECD's Working Party of the Trade Committee, as a part of its horizontal project on the circular economy, is currently investigating the extent to which trade restrictions are applied to recyclable metallic waste and scrap.

\subsection{Trade in second-hand goods}

From a global circular economy perspective, promoting the re-use of products through exports of second-hand goods would likely provide economic and environmental benefits to the global economy such as in used cars and second-hand textiles (Coffin et al., 2016; Valles, 2016; Shinkuma and Managi, 2011). In support of this argument, the OECD (2016a) policy guidance on resource efficiency makes recommendations for removing trade barriers to secondary goods and used products.

However, such benefits may be accompanied by potential concerns. From a domestic policy perspective of an exporting country, these exports could be considered as "leakage" from the official system such as in extended producer responsibility schemes (OECD, 2014b). Alternatively, second-hand good imports in some economies may hinder the transition towards energy efficient and low carbon economies due to slower market transformation or place additional pressures on the management of end-of-life products. As a consequence, countries importing second-hand goods may impose import restrictions on such products in order to increase oversight and control over these flows (Czaga and Fliess, 2005). Indeed, a number of developing countries mention the imposition of stricter controls or import restrictions on old and inefficient second-hand vehicles to meet their nationally determined contributions under the Paris climate accord (Brandi, 2017).

To the best of our knowledge, there is currently no comprehensive data on secondhand goods. One potential issue identified is the difficulty in distinguishing trade in secondhand products from products that are exported for recycling and recovery (OECD, 2004). While trade in second-hand goods is an important element of the interface between trade and the circular economy, the nature and magnitude of such trade flows are largely unknown and subject to further investigation.

\subsection{Trade in goods for refurbishment and remanufacturing}

There are increasing concerns related to international trade in refurbishment and remanufacturing of end-of-life products. A workshop by the European Union identified that industries have been facing issues of recovering their end-of-life products across borders for refurbishment and remanufacturing of such products since they are often legally classified as waste. In addition, cases were reported for remanufactured products that could be re-sold within a given jurisdiction however face transboundary issues when shipping across borders since they do not meet newly introduced standards and requirements at the time of exporting the remanufactured product (European Union, 2017). 
Such cases may require further investigation to understand the related issues and opportunities to facilitate such trade flows.

\subsection{International co-operation on circular economy value chains}

A transition towards a global circular economy is gradually gaining political attention. The aim is to promote the circular economy not only in a given jurisdiction but also by exploring synergies in working with other countries to achieve material circularity and ultimately decoupling of resource use from economic growth at the macro level. Such initiatives could also consider joint efforts to avoid environmentally harmful activities such as non-compliant, poorly regulated, and informal recovery operations. These concepts could be encouraged through multilateral frameworks and international trade negotiations (EASAC, 2015; Shinkuma and Managi, 2011; 2010).

One example is seen in the recent initiative called the North Sea Resource Roundabout among countries bordering the North Sea typically including the Netherlands and the United Kingdom (Green Alliance, n.d.). Discussions are taking place to better understand the quality and quantity of materials available in the region and identify priority materials for trade and the required processing capacity level. Other aims are made towards possible harmonisation of quality standards of materials, promoting demand for secondhand goods and secondary raw materials, and to remove unnecessary regulatory barriers.

\section{POTENTIAL WAYS FORWARD}

Despite the emerging political interest, very few studies are dedicated to investigating the interface of international trade and the transition to a more resource efficient and circular economy. Further research and empirical evidence is necessary to understand the possible synergies and trade-offs between the transition to a circular economy and international trade. The ultimate question is how could circular economy policies and trade policies be aligned to encourage the decoupling of resource consumption from economic growth at the global level without creating unnecessary barriers to international trade as well as undesirable environmental consequences. The scarce literature available on this question to date forms the strong motivation for further work in this area.

Importantly, identifying potential opportunities, challenges and knowledge gaps in the interface of trade and the circular economy would be beneficial to increase global material circularity to meet the needs of growing populations and their resource use as well as to mitigate associated environmental pressures. The framework provided in section 3 highlighting a number of potential research areas including: (i) the potential impacts of the circular economy transition on trade flows; (ii) the interaction of trade and domestic circular economy policies; (iii) trade in waste, scrap and secondary raw materials; and (iv) international co-operation on circular economy value chains, can be possible avenues to establish a better understanding of the interface between trade and the transition towards a circular economy. 


\section{References}

Associate Parliamentary Sustainable Resource Group (2013), "Exporting Opportunity? Putting UK waste to work at home and abroad", www.policyconnect.org.uk/apsrg/sites/site_apsrg/files/report/375/fieldreportdownload/apsrgreportexportingopportunitypdf.pdf.

Bernard, S. (2015), "North-south trade in reusable goods: Green design meets illegal shipments of waste", Journal of Environmental Economics and Management, Vol. 69, 2015, pp. 22-35, https://doi.org/10.1016/j.jeem.2014.10.004.

Brandi, C. (2017), “Trade elements in countries' contributions under the Paris Agreement”, Climate and Energy Issue Paper, March 2017, International Centre for Trade and Sustainable Development (ICTSD), Geneva, www.ictsd.org/sites/default/files/research/trade_elements_in_countries_climate_contributions.pdf.

Chatham House (2017), "Resource Trade database", https://resourcetrade.earth/ (accessed 11 August 2017).

Coffin, D. et al. (2016), "Examining Barriers to Trade in Used Vehicles", Office of Industries and Office of Economics U.S. International Trade Commission (USITC), www.usitc.gov/publications/332/used_vehicle_wp_id-44_final_web_0.pdf.

Czaga, P and B. Fliess (2005), "Used goods trade - a growth opportunity", OECD Observer, http://oecdobserver.org/news/archivestory.php/aid/1505/Used_goods_trade.html.

Dato, P. (2017), "Economic analysis of e-waste market", International Environmental Agreements: Politics, Law and Economics, pp 1-23, http://dx.doi.org/10.1007/s10784-017-9350-4.

De Backer, K. and S. Miroudot (2013), "Mapping Global Value Chains", OECD Trade Policy Papers, No. 159, OECD Publishing, Paris, http://dx.doi.org/10.1787/5k3v1trgnbr4-en.

EASAC (2015), "Circular economy: a commentary from the perspectives of the natural and social sciences", European Academies Science Advisory Council, November 2015, www.easac.eu/fileadmin/PDF_s/reports_statements/EASAC_Circular_Economy_Web.pdf.

European Commission (2015a), "Trade - Waste Shipment", http://ec.europa.eu/trade/import-and-exportrules/export-from-eu/waste-shipment/\#more (accessed 11 August 2017).

European Commission (2015b), "Circular Economy - Closing the loop - From Waste to Resources", Circular Economy Fact Sheet, December 2015, https:/ec.europa.eu/commission/sites/betapolitical/files/circular-economy-factsheet-waste-to-resources_en.pdf.

European Commission (2008), Waste Framework Directive, European Commission, http://ec.europa.eu/environment/waste/framework/revision.htm.

European Union (2017), "Promoting Remanufacturing, Refurbishment, Repair, and Direct Reuse", As a contribution to the G7 Alliance on Resource Efficiency, Workshop Report, 7-8 February 2017 
Brussels, Belgium, http://ec.europa.eu/environment/international issues/pdf/7 8 february 2017/workshop report $\mathrm{Br}$ ussels $7 \quad 8 \quad 02 \quad 2017 . p d f$.

Farrelly, T. et al. (2016), "Trading in waste: Integrating sustainable development goals and environmental policies in trade negotiations toward enhanced solid waste management in Pacific Islands countries and territories", Asia Pacific Viewpoint, Vol. 57, No.1, pp. 27-43, http://dx.doi.org/10.1111/apv.12110.

Green Growth Knowledge Platform (GGKP) (2015), "Can International Trade Increase Resource Efficiency?", Webinar, Green Growth Knowledge Platform, www.greengrowthknowledge.org/learning/can-international-trade-increase-resource-efficiency (accessed 6 February 2017).

Giljum, S. et al. (2014), "Material Footprint Assessment in a Global Input-Output Framework", Journal of Industrial Ecology, Vol. 19, No. 5, pp.792-804, http://dx.doi.org/10.1111/jiec.12214.

Green Alliance (n.d.), "North Sea Resource Roundabout - Developing solutions for trading recycled material across borders", www.green-alliance.org.uk/NSRR.php.

Higashida, K. (2012), "Trade in Secondhand Goods, Monitoring of Illegal Trade, and Import Quotas on Legal Trade", School of Economics, Kwansei Gakuin University, Discussion Paper Series, No. 90, http://192.218.163.163/RePEc/pdf/kgdp90.pdf.

Higashida, K. and S. Managi (2014), "Determinants of trade in recyclable wastes: evidence from commodity-based trade of waste and scrap", Environment and Development Economics, Vol. 19, No. 2, pp. 250-270, http://dx.doi.org/10.1017/S1355770X13000533.

Huisman, J. et al. (2015), "Countering WEEE Illegal Trade (CWIT) Summary Report, Market Assessment, Legal Analysis, Crime Analysis and Recommendations roadmap", Lyon, France, www.weeeforum.org/sites/default/files/documents/cwit_summary_report_final_medium_resolution_0.pdf.

Kellenberg, D. (2012), "Trading wastes", Journal of Environmental Economics and Management, Elsevier, vol. 64, No. 1, pp 68-87.

Kowalski, P. et al. (2015), "Participation of Developing Countries in Global Value Chains: Implication for Trade and Trade-Related Policies", OECD Trade Policy Papers, No. 179, OECD Publishing, Paris, http://dx.doi.org/10.1787/5js331fw0xxn-en.

Lacy, P. and J. Rutqvist (2015), Waste to Wealth: The Circular Economy Advantage, Palgrave Macmillan, Basingstoke.

McCarthy, A. and P. Börkey (2018), "Mapping Support for primary and secondary metal production", OECD Environment Working Papers, No. 135, OECD Publishing, Paris, https://doi.org/10.1787/4eaa61d4-en.

McCarthy, A., R. Dellink and R. Bibas (2018a), "The Macroeconomics of the Circular Economy Transition: A Critical Review of Modelling Approaches", OECD Environment Working Papers, No. 130, OECD Publishing, Paris, http://dx.doi.org/10.1787/af983f9a-en. 
McCarthy, A., M. Helf and P. Börkey (2018b), "Business Models for the Circular Economy - Opportunities and Challenges From a Policy Perspective", OECD Environment Working Papers, OECD Publishing, Paris, https://doi.org/10.1787/19970900.

OECD (forthcoming), "Indicators on Trade and Environment", OECD Trade and Environment Working Papers, OECD Publishing, Paris, https://doi.org/10.1787/18166881.

OECD (2018), Improving Markets for Recycled Plastics: Trends, Prospects and Policy Responses, OECD Publishing, Paris, http://dx.doi.org/10.1787/9789264301016-en.

OECD (2017), "Circular Economy", Presentation by Trade and Agriculture Directorate, Working Party on Resource Productivity and Waste (WPRPW), June 14-15, 2017, Paris.

OECD (2016a), Policy Guidance on Resource Efficiency, OECD Publishing, Paris, http://dx.doi.org/10.1787/9789264257344-en.

OECD (2016b), Extended Producer Responsibility: Updated Guidance for Efficient Waste Management, OECD Publishing, Paris, http://dx.doi.org/10.1787/9789264256385-en.

OECD (2015a), Material Resources, Productivity and the Environment, OECD Green Growth Studies, OECD Publishing, Paris, http://dx.doi.org/10.1787/9789264190504-en.

OECD (2015b), "An empirical assessment comparing input-output based and hybrid methodologies to measure demand-based material flows", 14 October 2015, [ENV/EPOC/WPEI(2015)1], Paris, France.

OECD, (2014a), Export Restrictions in Raw Materials Trade: Facts, Fallacies and Better Practices, OECD Publishing, Paris www.oecd.org/tad/benefitlib/export-restrictions-raw-materials.htm.

OECD (2014b), "The State of Play on Extended Producer Responsibility (EPR): Opportunities and Challenges", Issues Paper, Global Forum on Environment: Promoting Sustainable Materials Management through Extended Producer Responsibility (EPR), 17-19 June 2014, Tokyo, Japan, www.oecd.org/environment/waste/Global\%20Forum\%20Tokyo\%20Issues\%20Paper\%2030-52014.pdf.

OECD (2013), Interconnected Economies: Benefiting from Global Value Chains, OECD Publishing, Paris, http://dx.doi.org/10.1787/9789264189560-en.

OECD (2012a), OECD Environmental Outlook to 2050: The Consequences of Inaction, OECD Publishing, Paris, http://dx.doi.org/10.1787/9789264122246-en.

OECD (2012b), Sustainable Materials Management: Making Better Use of Resources, OECD Publishing, Paris, https://doi.org/10.1787/9789264174269-en.

OECD (2010), "Reducing barriers to international trade in non-hazardous recyclable materials: exploring the environmental and economic benefits, Part 1: A synthesis report", 18 March 2010, [COM/TAD/ENV/JWPTE(2008)27/FINAL], Paris, France.

OECD (2004), Economic Aspects of Extended Producer Responsibility, OECD Publishing, Paris. http://dx.doi.org/10.1787/9789264105270-en. 
OECD (2001), Extended Producer Responsibility: A Guidance Manual for Governments, OECD Publishing, Paris, http://dx.doi.org/10.1787/9789264189867-en.

Pacini, H. (2018), “Circular Economy: The New Normal”, Policy Brief No. 61, United Nations Conference on Trade and Development (UNCTAD), Geneva, https://unctad.org/en/pages/PublicationWebflyer.aspx?publicationid=2137.

Prag, A., T. Lyon and A. Russillo (2016), "Multiplication of Environmental Labelling and Information Schemes (ELIS): Implications for Environment and Trade", OECD Environment Working Papers, No. 106, OECD Publishing, Paris, http://dx.doi.org/10.1787/5jm0p33z27wf-en.

Preston, F. and J. Lehne (2017), “A Wider Circle? The Circular Economy in Developing Countries", Briefing, Energy, Environment and Resources Department, Chatham House, December 2017, www.chathamhouse.org/sites/files/chathamhouse/publications/research/2017-12-05-circulareconomy-preston-lehne-final.pdf.

Rabobank (2015), "The potential of the circular economy", https://economics.rabobank.com/publications/2015/july/the-potential-of-the-circular-economy/.

Sauvage, J. (2014), "The Stringency of Environmental Regulations and Trade in Environmental Goods", OECD Trade and Environment Working Papers, No. 2014/03, OECD Publishing, Paris. http://dx.doi.org/10.1787/5jxrjn7xsnmq-en

Secretariat of the Basel Convention (2013), "Amendment proposals from the Secretariat of the Basel Convention to the Harmonized System Committee, World Customs Organization," Discussion Note, www.basel.int/Portals/4/download.aspx?d=UNEP-CHW-WASTELST-CONHarmonizedSystemCommitteeAmendment-20130402.English.pdf.

Shinkuma, T. and S. Managi (2011), Waste and Recycling: Theory and Empirics, Routledge, New York, https://doi.org/10.4324/9780203828014.

Shinkuma, T. and S. Managi (2010), "On the effectiveness of a license scheme for E-waste recycling: The challenge of China and India", Environmental Impact Assessment Review, Vol 30, No. 4, pp. 262-267, http://dx.doi.org/10.1016/j.eiar.2009.09.002.

Valles, G. (2016), "The Circular Economy in International Trade", United Nations Conference on Trade and Development (UNCTAD), Geneva, http://unctad.org/en/pages/newsdetails.aspx?OriginalVersionID=1400.

Wiedmann, T. et al. (2013), "The material footprint of nations", Proceedings of the National Academy of Sciences, Vol. 112, No. 20, pp.6271-6276, http://dx.doi.org/10.1073/pnas.1220362110.

WTO (2010), World Trade Report 2010: Trade in natural resources, WTO Secretariat, World Trade Organization, Geneva, www.wto.org/english/res_e/booksp_e/anrep_e/world_trade_report10_e.pdf.

Yanai, A. (2014), Environmental provisions in Japanese regional trade agreements with developing countries, IDE DISCUSSION PAPER No. 467, March 2014, https://ir.ide.go.jp/?action=repository uri\&item id=37709\&file $\mathrm{id}=22 \&$ file no $=1$. 